\title{
Optimization of silver-containing bioglass nanoparticles envisaging biomedical applications
}

\author{
A.C. Vale ${ }^{\mathrm{a}, \mathrm{b}}$, P.R. Pereira ${ }^{\mathrm{a}, \mathrm{b}}$, A.M. Barbosa ${ }^{\mathrm{b}, \mathrm{c}}$, E. Torrado ${ }^{\mathrm{b}, \mathrm{c}}$, N.M. Alves ${ }^{\mathrm{a}, \mathrm{b}, *}$ \\ a 3B's Research Group, I3Bs - Research Institute on Biomaterials, Biodegradables and Biomimetics, University of Minho, Headquarters of the European Institute of \\ Excellence on Tissue Engineering and Regenerative Medicine, AvePark, Barco, 4805-017, Guimarães, Portugal \\ ${ }^{\mathrm{b}}$ ICVS/3B's PT Associate Laboratory, Guimarães, Portugal \\ ${ }^{\mathrm{c}}$ Life and Health Sciences Research Institute (ICVS), School of Health Sciences, University of Minho, Braga, Portugal
}

\section{A R T I C L E I N F O}

\section{Keywords:}

Nanoparticles

Bioglass $^{\varpi}$ (BG)

Silver (Ag)

Antibacterial activity

\begin{abstract}
A B S T R A C T
Bioglass nanoparticles (BGs) are of outmost importance in the biomedical field, because their unique characteristics, namely osteoconductivity and osteoinductivity, and also in certain conditions, angiogenic and bactericidal properties. In this work, novel bioglass nanoparticles containing silver (AgBGs) were synthesized by a sol-gel method, adopting different thermal treatments to obtain new nanoparticles with bioactive and antibacterial features. This is the first systematic study of the effect of the thermal treatment on the properties of AgBGs. The effect of the studied thermal treatments on the properties of synthesized nanoparticles was analyzed by several characterization techniques: FT-IR, XRD, S-TEM, SEM-EDS and Zeta potential. FT-IR allowed the identification of the characteristic peaks of the nanoparticles and XRD revealed the presence of the characteristic peaks of an apatite-like phase. By S-TEM analysis it was found that the produced nanoparticles are dense and have a diameter $<200 \mathrm{~nm}$. The SEM micrographs showed their surface morphology and Zeta potential measurements were performed to study their suspension stability. Additionally, in vitro bioactivity tests confirmed their bioactive potential and the microbiological tests evidenced their bactericidal effect. These promising AgBGs could be incorporated either in 2D or 3D structures for several biomedical applications, namely in the orthopedic and dental fields.
\end{abstract}

\section{Introduction}

Nanoparticles have been attracted much interest by the scientific community, [1-4] essentially due to their large surface and small size to volume ratio, chemical and promising biological properties [5-8].

Bioactive glass is a particularly interesting biomaterial, since it is the most bioactive material available that is dissolvable under biological conditions (in vitro and in vivo) and provides biologically active ions, which enable the bone regeneration, and also the soft tissue regeneration and wound healing [9-11]. Bioglass ${ }^{\circledR}$ is generally composed by $\mathrm{SiO}_{2}-\mathrm{CaO}-\mathrm{P}_{2} \mathrm{O}_{5}$ and $\mathrm{Na}_{2} \mathrm{O}$ and it can mainly be synthesized through two approaches: melting or sol-gel $[7,12,13]$. Since variations in the ratio of precursors or in the production apparatus could result in distinct nanoparticles' morphology and shape [5], several bioglass nanoparticles have been synthesized since 1969 [10,11,14]. The silica amount present in the bioglass obtained by the sol-gel methodology or melt process can be much higher in the sol-gel methodology [14].
Furthermore, the sol-gel approach allows the synthesis of nanoparticles with a higher surface area, implying faster dissolution rate and, consequently, faster formation of hydroxycarbonated apatite [14,15], and usually, sol-gel processed nanoparticles present a specific surface area and a pore volume two orders higher than the ones derived from the melting technique $[10,12]$.

Since the infection is one of the most challenges during implantation that can cause the implant failure or tissue necrosis [16], the incorporation of antibacterial metallic ions, like silver $\left(\mathrm{Ag}^{+}\right)$, zinc $\left(\mathrm{Zn}^{2+}\right)$, copper $\left(\mathrm{Cu}^{+} / \mathrm{Cu}^{2+}\right)$, cerium $\left(\mathrm{Ce}^{3+}\right)$ and gallium $\left(\mathrm{Ga}^{3+}\right)$ into the composition of biomaterials has been reveal a promising alternative to prevent and treat bacterial infections [7,16-21]. It is well known that, after an implant being introduced into the body, there is a risk of bacterial infection caused by the adherence and colonization of bacteria on the surface of implants [22]. In context of antibacterial biomaterials, silver and silver-based materials have emerged as a new generation of versatile and effective antibacterial agents, being biocompatible and, in

\footnotetext{
* Corresponding author at: 3B's Research Group, I3Bs - Research Institute on Biomaterials, Biodegradables and Biomimetics, University of Minho, Headquarters of the European Institute of Excellence on Tissue Engineering and Regenerative Medicine, AvePark, Barco, 4805-017, Guimarães, Portugal.

E-mail address: nalves@dep.uminho.pt (N.M. Alves).
} 
a given concentration, non-toxic to human cells [22-24]. Particularly, silver-doped bioglass nanoparticles have been studied in recent years, and the sol-gel-derived Ag-doped BG nanoparticles have revealed bacteriostatic and bactericidal properties, while preserving their bioactivity $[16,25]$. Bellantone and co-workers [26] developed $\mathrm{SiO}_{2}-\mathrm{CaO}-$ $\mathrm{P}_{2} \mathrm{O}_{5}-\mathrm{Ag}_{2} \mathrm{O}$ nanoparticle systems, which presented antimicrobial properties without affecting their bioactivity. In fact, $\mathrm{Ag}$ reduces the risk of microbial infections, although it is not yet fully explained through which mechanism silver ions have toxicity in bacteria. El-Kady and coworkers [12] also developed silver doped bioglass nanoparticles by a sol-gel method, where the silver dissolution rate was evaluated and the results showed that with higher silver content, the dissolution rate is also higher. Furthermore, these nanoparticles produced by El-Kady et al. showed antibacterial effect against Staphylococcus aureus and Escherichia coli bacteria [12]. Catauro and co-workers [27] developed nanoparticles with $\mathrm{Na}_{2} \mathrm{O}^{\cdot} \mathrm{CaO} \cdot 2 \mathrm{SiO}_{2}$ composition and silver, once again, through the sol-gel methodology, and their antibacterial tests showed that, after $2 \mathrm{~h}$, the completely inhibition in Escherichia coli and Staphylococcus mutans occurred. According to Vernè and co-workers [28], it is well known that silver doped biomaterials are important in preventing bacterial growth, however the connection between silver content, released ions profile and their toxic effects are still unknown [28]. Goh and co-workers [7] produced silver and copper doped bioglass nanoparticles by quick alkali-mediated sol-gel method with different concentrations, to study the relation of their ion release profile with their antibacterial performances. Their results showed that the morphology of doped and non-doped nanoparticles were similar. Furthermore, their silver doped bioglass have much higher dissolution profiles than copper doped BG during the first day, concluding that silver doped BG nanoparticles are better antibacterial agents than copper doped BG nanoparticles against Escherichia coli bacteria [7]. Recently, Mariappan and Ranza [29] reported the structural, dielectric, biocompatibility and antibacterial properties of nano-sized calcium phosphosilicate bioglass ceramics doped with silver $(<6 \mathrm{~mol} \%)$ also produced via sol-gel method. These bioceramic nanoparticles were heated at various temperatures $\left(100^{\circ} \mathrm{C}, 400^{\circ} \mathrm{C}\right.$ and $\left.600^{\circ} \mathrm{C}\right)$, but it was not clarified the effect of heat treatment on their size and shape. However, this study showed good bioactivity and antibacterial properties of these nanoparticles against $E$. coli and $S$. aureus, emphasizing that their antibacterial properties are correlated with their dielectric constant [29].

In the present work, novel AgBGs were synthesized by the sol-gel method, testing different thermal treatments. It should be pointed that, as far as we know, this is the first time that a systematic study of the effect of the chosen thermal treatment on the properties of the silvercontaining bioglass nanoparticles was analyzed. The following treatments were adopted: 1 day at $50{ }^{\circ} \mathrm{C}, 1 \mathrm{~h}$ at $100^{\circ} \mathrm{C}, 2 \mathrm{~h}$ at $100{ }^{\circ} \mathrm{C}, 2 \mathrm{~h}$ at $90{ }^{\circ} \mathrm{C}+1 / 2 \mathrm{~h}$ at $100^{\circ} \mathrm{C}, 100{ }^{\circ} \mathrm{C} / \mathrm{h}+1 / 2 \mathrm{~h}$ at $400{ }^{\circ} \mathrm{C}, 100^{\circ} \mathrm{C} / \mathrm{h}+1 / 2 \mathrm{~h}$ at $500{ }^{\circ} \mathrm{C}, 100^{\circ} \mathrm{C} / \mathrm{h}+1 / 2 \mathrm{~h}$ at $580{ }^{\circ} \mathrm{C}, 100{ }^{\circ} \mathrm{C} / \mathrm{h}+1 / 2 \mathrm{~h}$ at $700^{\circ} \mathrm{C}$, and also, the powder gel (i.e. nanoparticles without thermal treatment). The aim of this work was to analyze the effect of such thermal treatments on the morphological, bioactivity and antibacterial properties of the synthesized AgBGs nanoparticles. Those distinct nanoparticles were analyzed by Fourier Transform infrared spectroscopy (FT-IR), Zeta potential, Xray diffraction (XRD), scanning transmission electron microscopy (STEM) and scanning electron microscopy with elemental analysis (SEMEDS). In vitro bioactivity tests were performed to demonstrate the bioactivity behavior of the produced AgBGs. Finally, antibacterial tests were also performed against Staphylococcus aureus and Escherichia coli bacteria to evaluate their bactericidal action.

\section{Materials and methods}

\subsection{Materiais}

Ammonium phosphate dibasic, calcium nitrate tetra hydrate $99 \%$, ethanol absolute, ammonia water (ammonium hydrogen phosphate
98\%, maximum of $33 \% \mathrm{NH}_{3}$ ), sodium chloride ( $\mathrm{NaCl}$ ), magnesium chloride hexahydrate $\left(\mathrm{MgCl}_{2} \cdot 6 \mathrm{H}_{2} \mathrm{O}\right)$, sodium sulphate $\left(\mathrm{Na}_{2} \mathrm{SO}_{4}\right)$, 2-(4(2-hydroxyethyl)-1-piperazinyl) ethanesulfonic acid (HEPES, $\mathrm{C}_{8} \mathrm{H}_{18} \mathrm{~N}_{2} \mathrm{O}_{4} \mathrm{~S}$ ), hydrochloric acid $(\mathrm{HCl})$ and silver nitrate $\left(\mathrm{AgNO}_{3}\right)$ were acquired from Sigma-Aldrich (St. Louis, MO, USA). Tetraethyl orthosilicate (TEOS, 99.90\%), sodium hydrogen carbonate $\left(\mathrm{NaHCO}_{3}\right)$, dipotassium hydrogen phosphate trihydrate $\left(\mathrm{K}_{2} \mathrm{HPO}_{4} \cdot 3 \mathrm{H}_{2} \mathrm{O}\right)$, potassium chloride $(\mathrm{KCl})$ and calcium chloride $\left(\mathrm{CaCl}_{2}\right)$ were purchased by Merck KGaA (Darmstadt, Germany). Nitric acid monohydrate (69\%), potassium chloride $(\mathrm{KCl})$ were obtained by VWR International (UK). Sodium hydroxide $(\mathrm{NaOH})$ was purchased from Fisher Chemical (Fisher Scientific UK, Leics, UK). For antibacterial tests, Mueller-Hinton agar (MHA) medium was purchased from ThermoScientific (Thebarton, SA, Australia) and standardized cultures of Staphylococcus aureus (ATCC 29213TM) and Escherichia coli (ATCC 25922TM) with $1.5 \times 10^{8}$ Colony Forming Units (CFU) were purchased from the American Type Culture Collection (Manassas, VA, USA).

\subsection{Synthesis of silver-containing bioglass nanoparticles (AgBGs)}

The synthesis followed the protocol for production of ternary glass nanoparticles $\left[\mathrm{SiO}_{2}-\mathrm{CaO}-\mathrm{P}_{2} \mathrm{O}_{5}\right.$ (mol\%): 55-40-5] [30] with some modifications, based on the procedure proposed by Vulpoi et al. [31], Delben et al. [25], and also based on the El-Kady and co-workers' protocol [12]. These AgBGs were produced by a sol-gel methodology, containing the following composition: $\left[\mathrm{SiO}_{2}-\mathrm{CaO}-\mathrm{P}_{2} \mathrm{O}_{5}-\mathrm{Ag}_{2} \mathrm{O}(\mathrm{mol}\right.$ $\%$ ):56-30-4-10]. Briefly, at room temperature, TEOS was mixed with osmotized water, and then added together to ethanol absolute. The $\mathrm{pH}$ value of this mixture was adjusted to 2 with the addition of nitric acid, and this reaction was kept stirring for $60 \mathrm{~min}$ to produce a solution A. Then, for producing the solution $\mathrm{B}$, calcium nitrate tetrahydrate, ammonium phosphate dibasic and silver nitrate were added to osmotized water and the $\mathrm{pH}$ value was adjusted to 11.5 with ammonium hydroxide solution. The reaction mixture B was kept under stirring for 60 min. Under smooth stirring, the solution A was slowly added to the solution B drop-by-drop. During this step, the $\mathrm{pH}$ value of solution $\mathrm{B}$ was maintained at 11.5 using ammonia hydroxide solution, and the final solution was kept under stirring for $48 \mathrm{~h}$. Then, after washing three times, the precipitation of gel particle with osmotized water, eight different thermal treatments were applied: $50{ }^{\circ} \mathrm{C}, 1$ day; $100^{\circ} \mathrm{C}, 1 \mathrm{~h}$; $100{ }^{\circ} \mathrm{C}, 2 \mathrm{~h} ; \quad 90^{\circ} \mathrm{C}, 2 \mathrm{~h}+100{ }^{\circ} \mathrm{C}, \frac{1 / 2}{\mathrm{~h}} ; \quad 100^{\circ} \mathrm{C} / \mathrm{h}+400{ }^{\circ} \mathrm{C}, 1 / 2 \mathrm{~h} ; \quad 100{ }^{\circ} \mathrm{C} /$ $\mathrm{h}+500{ }^{\circ} \mathrm{C}, 1 / 2 \mathrm{~h} ; 100^{\circ} \mathrm{C} / \mathrm{h}+580^{\circ} \mathrm{C}, 1 / 2 \mathrm{~h} ; 100^{\circ} \mathrm{C} / \mathrm{h}+700^{\circ} \mathrm{C}, 1 / 2 \mathrm{~h}$.

\subsection{Characterization of silver-containing bioglass nanoparticles}

Firstly, Fourier Transform infrared spectroscopy was performed to analyze all calcined silver-containing bioglass nanoparticles powders and also the Ag-BG powder without thermal treatment. FT-IR spectra were recorded from 600 to $1700 \mathrm{~cm}^{-1}$, using a FT-IR equipment (Infrared spectrum-Jasco), in attenuated total reflectance (ATR) mode.

The Zeta potential analysis of the produced AgBGs with different thermal treatments was conducted using a Zetasizer equipment (Nano ZS, Malvern Instruments, UK) with a Dispersion Technology Software (DTS). For this analysis, AgBGs suspensions $\left(0.3 \mathrm{mg} \mathrm{mL}^{-1}\right)$ in saline solution $(0.15 \mathrm{M} \mathrm{NaCl}, \mathrm{pH}=5.5)$ were prepared and, to avoid nanoparticle's agglomeration, suspensions were kept on the ultrasonic bath during $15 \mathrm{~min}$ before the each measurement.

Then, the morphology and composition of the produced glass powders were analyzed using the Scanning Electron Microscope (SEM, JSM-6010 LV, JEOL, Japan) coupled with dispersive X-ray spectroscopy (INCAx-Act, PentaFET Precision, Oxford Instruments, USA) equipment. The elemental composition of the produced AgBGs nanoparticles was determined by EDS using the High-Resolution Field Emission Scanning Electron Microscope with Focused Ion Beam (Auriga compact, Zeiss, DE). The scanning transmission electron microscopy (S-TEM) was performed using the Nova NanoSEM 200 (FEI company, USA) equipment. 
Also, X-ray diffraction (XRD) experiments were performed on a AXS D8 Discover equipment (Bruker, USA) with $\mathrm{Cu}-\mathrm{K} \alpha$ radiation $(\lambda=1.54060 \AA)$, scanning from $15^{\circ}$ to $60^{\circ}$ at a speed of $0.04^{\circ} \mathrm{s}^{-1}$, where the phase identification was performed using analytical software EVA and the crystalline phases were indexed using the ICDD 2015 database (International Center for Diffraction Data).

\subsection{In vitro bioactivity studies}

Standard in vitro bioactivity studies were conducted by immersion of the distinct AgBGs produced in simulated body fluid solution, SBF, which is usually used because it really simulates the concentration of ionic species present in human blood plasma. These bioactivity tests were carried out using the modified-simulated body fluid solution (mSBF 1.5x) following the Oyane and co-workers procedures [32,33]. Thus, this solution was prepared dissolving sodium chloride $(\mathrm{NaCl})$, sodium sulphate $\left(\mathrm{Na}_{2} \mathrm{SO}_{4}\right)$, magnesium chloride hexahydrate $\left(\mathrm{MgCl}_{2} \cdot 6 \mathrm{H}_{2} \mathrm{O}\right)$, di-Potassium hydrogen phosphate trihydrate $\left(\mathrm{K}_{2} \mathrm{HPO}_{4} \cdot 3 \mathrm{H}_{2} \mathrm{O}\right)$, calcium chloride $\left(\mathrm{CaCl}_{2}\right)$, potassium chloride $(\mathrm{KCl})$, sodium hydrogen carbonate $\left(\mathrm{NaHCO}_{3}\right)$, sodium carbonate $\left(\mathrm{Na}_{2} \mathrm{CO}_{3}\right)$, sodium hydroxide $(\mathrm{NaOH})$ and 2-(4-(2-hydroxyethyl)-1-piperazinyl) ethanesulfonic acid (HEPES, $\mathrm{C}_{8} \mathrm{H}_{18} \mathrm{~N}_{2} \mathrm{O}_{4} \mathrm{~S}$ ) in UPW at $36.5^{\circ} \mathrm{C}$, then the final $\mathrm{pH}$ was adjusted to 7.4. All AgBGs powders were put in contact with a carbon tape (to stick) and immersed in $25 \mathrm{~mL}$ of $\mathrm{m}$-SBF $1.5 \mathrm{x}$ during 7 days at $37^{\circ} \mathrm{C}$. After being removed from SBF solution, these coverslips were cleaned with UPW and dried at room temperature.

The formation of apatite on the surface of the films was characterized by their surface analysis, using distinct techniques such as scanning electron microscopy (JSM-6010 LV, JEOL, Japan) coupled with energy dispersive X-ray spectroscopy (INCAx-Act, PentaFET Precision, Oxford Instruments), Fourier Transform infrared spectroscopy (Perkin-Elmer 1600 series equipment, USA), and X-ray diffraction (Bruker AXS D8 Discover, USA).

\subsection{Microbiological analysis}

In order to test the antimicrobial properties of all AgBGs powders, the disk diffusion methodology was performed. Briefly, Mueller-Hinton agar plates were inoculated with a suspension of Staphylococcus aureus $(+)$ and Escherichia coli $(-)$, both with OD600 of approximately 0.1 $\left(1.5 \times 10^{8} \mathrm{CFU} \mathrm{mL}{ }^{-1}\right)$. Then, AgBGs $\left(90^{\circ} \mathrm{C}, 2 \mathrm{~h}+100^{\circ} \mathrm{C}, 1 / 2 \mathrm{~h} ; 100^{\circ} \mathrm{C} /\right.$ $\mathrm{h}+400{ }^{\circ} \mathrm{C}, 1 / 2 \mathrm{~h} ; \quad 100{ }^{\circ} \mathrm{C} / \mathrm{h}+500{ }^{\circ} \mathrm{C}, 1 / 2 \mathrm{~h} ; \quad 100{ }^{\circ} \mathrm{C} / \mathrm{h}+580{ }^{\circ} \mathrm{C}, 1 / 2 \mathrm{~h}$; $100{ }^{\circ} \mathrm{C} / \mathrm{h}+700^{\circ} \mathrm{C}, 1 / 2 \mathrm{~h}$; and also, nanoparticles without thermal treatment), BGs and $\mathrm{AgNO}_{3}$ powders were placed on top of the inoculated agar plates, and incubated for $16 \mathrm{~h}$ at $37^{\circ} \mathrm{C}$. The formation of an inhibition zone surrounding nanoparticles powders was used as indicator of antibacterial activity.

\section{Results and discussion}

\subsection{FT-IR analysis}

FT-IR spectra of the produced AgBGs are shown in Fig.1. Characteristic silicate bands are observed in all spectra, assigned to the vibration peaks 1085 and $800 \mathrm{~cm}^{-1}$, respectively: asymmetric stretching mode and symmetric stretching vibration of $\mathrm{Si}-\mathrm{O}-\mathrm{Si}[7,12,21,34]$. Furthermore, $\mathrm{P}-\mathrm{O}$ antisymmetric stretching was assigned to a band at $1000-1100 \mathrm{~cm}^{-1}$, which can be overlapped with that of $\mathrm{Si}-\mathrm{O}-\mathrm{Si}$ asymmetric stretching [7]. Additionally, the band at $600 \mathrm{~cm}^{-1}$ indicated the antisymmetric bending of $\mathrm{PO}_{4}{ }^{3-}$, due to the presence of phosphorus under the form of orthophosphate [7]. The band at $950 \mathrm{~cm}^{-1}$ confirmed the Ca presence due to the $\mathrm{Si}-\mathrm{O}-\mathrm{Ca}$ stretching containing non-bridging oxygen [30,34]. Moreover, according with Luz and Mano [30], the existence of bands on $1400-1300 \mathrm{~cm}^{-1}$ is related with calcium nitrate precursor, due to the $\mathrm{N}=\mathrm{O}$ bending. However, it can be seen that these bands tend to disappear with higher temperature treatments, which is related to the $\mathrm{Ca}\left(\mathrm{NO}_{3}\right)_{2}$ decomposition [30]. In addition, the presence of band $1630 \mathrm{~cm}^{-1}$ in the FTIR spectra of all samples, confirmed the hygroscopic nature of the silicate glass, since it was attributed to the bending vibration modes of $\mathrm{O}-\mathrm{H}$ groups, due to the residual water absorbed in the nanoparticles [7].

\subsection{Zeta-potential ( $\zeta)$ analysis}

Zeta potential analysis was performed to analyze the stability of the produced AgBGs nanoparticles suspended in a saline solution $(0.15 \mathrm{M}$ $\mathrm{NaCl}, \mathrm{pH}=5.5$ ) and the results are shown in Table 1 . Since the $\zeta$ potential is obtained through the electrophoretic mobility of the particles, this parameter gives us the degree of repulsion between adjacent similarly charged particles and, if the potential value is above $\pm 30 \mathrm{mV}$,

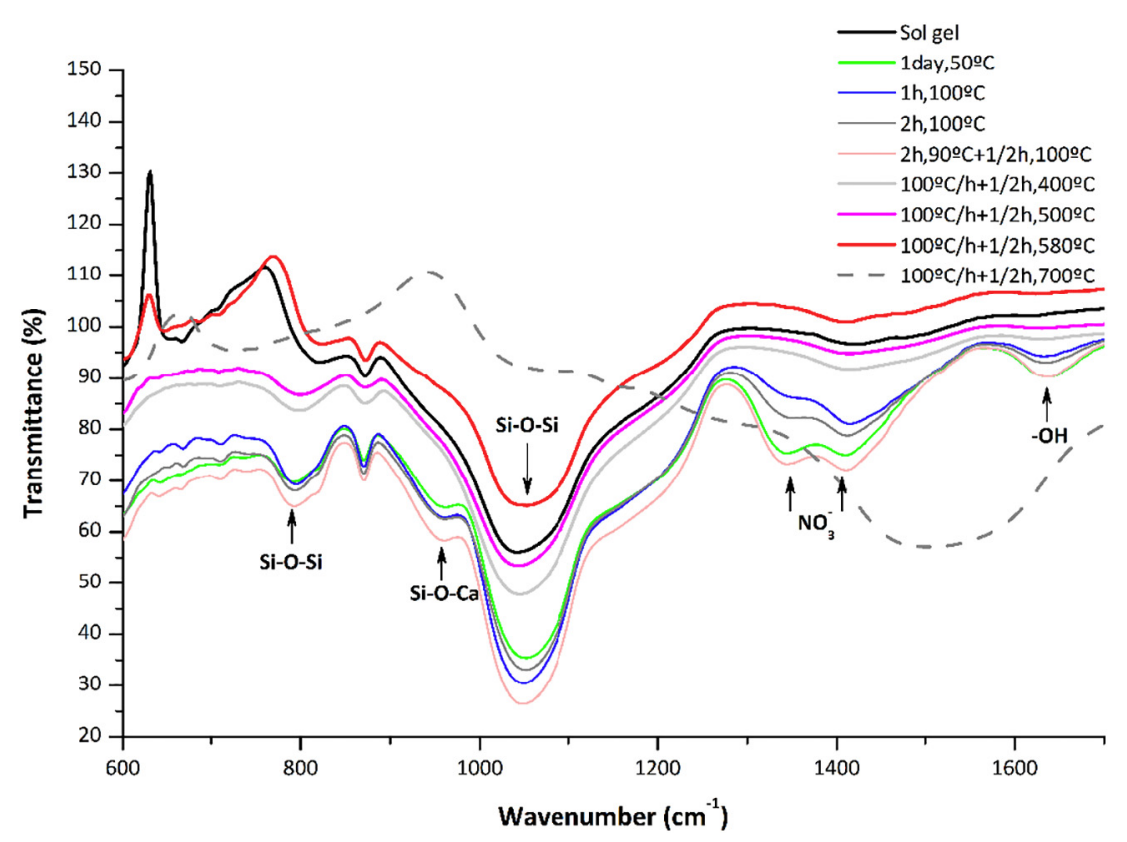

Fig. 1. FTIR spectra of AgBGs (10 mol\%Ag) with different thermal treatments. 
Table 1

Mean and standard deviation values of the Zeta potential measured for distinct AgBGs suspended in $0.15 \mathrm{M} \mathrm{NaCl}$ ( $\mathrm{pH}=5.5$ ).

\begin{tabular}{ll}
\hline AgBGs & Zeta potential (mV) \\
\hline Powder gel & $-14.40 \pm 0.11$ \\
$50{ }^{\circ} \mathrm{C}, 1$ day & $-14.90 \pm 1.34$ \\
$100^{\circ} \mathrm{C}, 1 \mathrm{~h}$ & $-15.00 \pm 0.82$ \\
$100{ }^{\circ} \mathrm{C}, 2 \mathrm{~h}$ & $-11.80 \pm 0.66$ \\
$90^{\circ} \mathrm{C}, 2 \mathrm{~h}+100^{\circ} \mathrm{C}, 1 / 2 \mathrm{~h}$ & $-25.80 \pm 0.98$ \\
$100^{\circ} \mathrm{C} / \mathrm{h}+400^{\circ} \mathrm{C}, 1 / 2 \mathrm{~h}$ & $-10.00 \pm 0.71$ \\
$100^{\circ} \mathrm{C} / \mathrm{h}+500^{\circ} \mathrm{C}, 1 / 2 \mathrm{~h}$ & $-11.50 \pm 0.36$ \\
$100{ }^{\circ} \mathrm{C} / \mathrm{h}+580^{\circ} \mathrm{C}, 1 / 2 \mathrm{~h}$ & $-13.80 \pm 0.46$ \\
$100^{\circ} \mathrm{C} / \mathrm{h}+700^{\circ} \mathrm{C}, 1 / 2 \mathrm{~h}$ & $-12.80 \pm 0.15$ \\
\hline
\end{tabular}

the repulsive charges present in the nanoparticles will avoid their agglomeration, ensuring their stability in a solution [35]. In fact, it is important to mention that particle agglomeration is not only promoted because of the post-synthesis thermal treatment, but also by the decrease in particles' surface charge during their synthesis [15,28]. Pure silica particles have a zero charge in a $\mathrm{pH}$ value of about 2 , meaning that for $\mathrm{pH}$ values higher than 2 , their surface is negatively charged $\left(-\mathrm{O}^{-}\right.$groups). During bioactive glass synthesis, the $\mathrm{pH}$ value is quickly raised to 11 in order to promote the formation of particles. Due to the high $\mathrm{pH}$ value, particles are electrostatically repulsed from each other and no agglomeration should occur. However, the addition of $\mathrm{Ca}^{2+}$ and $\mathrm{Ag}+$ ions in the media and their adsorption at the particles surface decreases their surface charge and thus leads to particles agglomeration. [15] On the other hand, according to Lu and co-workers [36], a negative value of Zeta potential engages the bioactive character of bioglass nanoparticles, since the apatite formation appeared to be favored by negative surfaces [36].

Based on the results presented in Table 1 , it can be concluded that the thermal treatment $100{ }^{\circ} \mathrm{C} / \mathrm{h}+400{ }^{\circ} \mathrm{C}, 1 / 2 \mathrm{~h}$ led to the lowest Zeta potential, and contrasting, the treatment $90^{\circ} \mathrm{C}, 2 \mathrm{~h}+100^{\circ} \mathrm{C}, 1 / 2 \mathrm{~h}$ contributed to the highest value, probably due to a lower adsorption of $\mathrm{Ca}^{2+}$ and $\mathrm{Ag}^{+}$ions at the particles surface. So, these results evidenced that $\operatorname{AgBGs}\left(100^{\circ} \mathrm{C} / \mathrm{h}+400^{\circ} \mathrm{C}, 1 / 2 \mathrm{~h}\right)$ with more cations adsorbed at their surface will exhibit higher tendency to agglomerate than the AgBGs $\left(90^{\circ} \mathrm{C}, 2 \mathrm{~h}+100^{\circ} \mathrm{C}, 1 / 2 \mathrm{~h}\right.$ ), which should be more stable in suspension. For higher calcination temperatures, $\operatorname{AgBGs}\left(100^{\circ} \mathrm{C} / \mathrm{h}+580^{\circ} \mathrm{C}, 1 / 2 \mathrm{~h}\right)$ presented higher Zeta potential than $\operatorname{AgBGs}\left(100^{\circ} \mathrm{C} / \mathrm{h}+700{ }^{\circ} \mathrm{C}, 1 / 2 \mathrm{~h}\right)$, $\operatorname{AgBGs}\left(100^{\circ} \mathrm{C} / \mathrm{h}+500^{\circ} \mathrm{C}, 1 / 2 \mathrm{~h}\right)$ and $\operatorname{AgBGs}\left(100^{\circ} \mathrm{C} / \mathrm{h}+400{ }^{\circ} \mathrm{C}, 1 / 2 \mathrm{~h}\right)$. Comparing the Zeta potential values previously obtained by our group for BGs $(-15.7 \pm 0.5 \mathrm{mV})$ with the results obtained in the present work, it can be concluded that AgBGs and BG nanoparticles present similar stability. Also, it can be concluded that the AgBGs with higher stability are: $\operatorname{AgBGs}\left(100{ }^{\circ} \mathrm{C} / \mathrm{h}+580^{\circ} \mathrm{C}, 1 / 2 \mathrm{~h}\right)$ followed by AgBGs $\left(100{ }^{\circ} \mathrm{C} / \mathrm{h}+1 / 2 \mathrm{~h}, 700^{\circ} \mathrm{C}\right), \operatorname{AgBGs}\left(100^{\circ} \mathrm{C} / \mathrm{h}+1 / 2 \mathrm{~h}, 500^{\circ} \mathrm{C}\right)$ and $\mathrm{AgBGs}$ $\left(100^{\circ} \mathrm{C} / \mathrm{h}+400^{\circ} \mathrm{C}, 1 / 2 \mathrm{~h}\right)$, because they present higher Zeta potential values and, consequently, higher stability in suspension.

\subsection{Analysis of the nanoparticles' morphology}

The characterization of nanoparticles' morphology by SEM is shown in Fig. 2(A-I). It can be seen that the Fig. 2A (powder gel) presents an unconsolidated spheroids, because the obtained structures had no thermal treatment, presenting a huge range of diameters. Moreover, these powder gel nanoparticles demonstrated a tendency to aggregate. Indeed, this occurs because there is a reduction of the energy on the surface, when van der Walls forces actuate on these particles, and their final diameter results from the competition process between repulsive and attraction forces [37]. As Luz et al. [35] mentioned, the calcination step is crucial for the stabilization of the particles and also for the fixation of calcium, phosphorus into glassy structure. From the results presented onto Fig. 2, it can be seen that for the thermal treatments at lower temperatures (Fig. 2B-E), the nanoparticles have a more
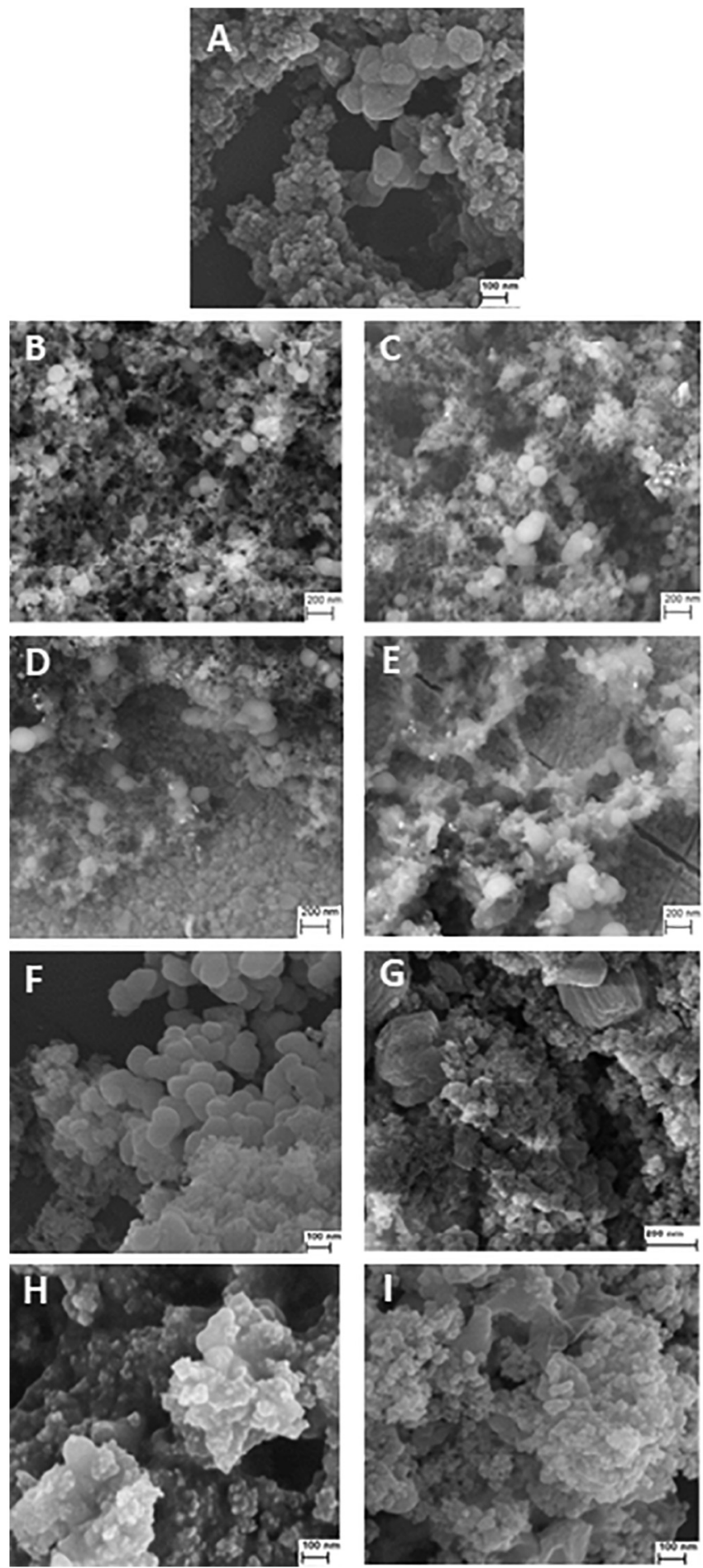

Fig. 2. Representative SEM micrographs of the AgBGs nanoparticles' surface (AI). Scale bar represents $100 \mathrm{~nm}$ (A,F,H,I) and $200 \mathrm{~nm}$ (B-E,G).

spherical form than those produced at higher temperatures. These spheroids with very small diameter and an aggregated structure can be observed both in Fig. 2B ( $50^{\circ} \mathrm{C}, 1$ day) and Fig. $2 \mathrm{C}\left(100^{\circ} \mathrm{C}, 1 \mathrm{~h}\right)$. In Fig. $2 \mathrm{D}\left(100^{\circ} \mathrm{C}, 2 \mathrm{~h}\right)$, the spheroids also present a wide range of diameters with an aggregated structure. Few spheroids are observed in Fig. $2 \mathrm{E}\left(90^{\circ} \mathrm{C}, 2 \mathrm{~h}+100^{\circ} \mathrm{C}, 1 / 2 \mathrm{~h}\right)$, but in this case they present more uniformity in their diameters. In fact, nanoparticles shown in Fig. $2 \mathrm{~F}$ $\left(100^{\circ} \mathrm{C} / \mathrm{h}+400^{\circ} \mathrm{C}, 1 / 2 \mathrm{~h}\right)$, Fig. $2 \mathrm{G}\left(100^{\circ} \mathrm{C} / \mathrm{h}+500^{\circ} \mathrm{C}, 1 / 2 \mathrm{~h}\right)$, Fig. $2 \mathrm{H}$ $\left(100{ }^{\circ} \mathrm{C} / \mathrm{h}+580^{\circ} \mathrm{C}, 1 / 2 \mathrm{~h}\right)$ and Fig. 2I $\left(100^{\circ} \mathrm{C} / \mathrm{h}+700^{\circ} \mathrm{C}, 1 / 2 \mathrm{~h}\right)$ did not present a spherical structure at all, but a flake-like structure. Regarding 

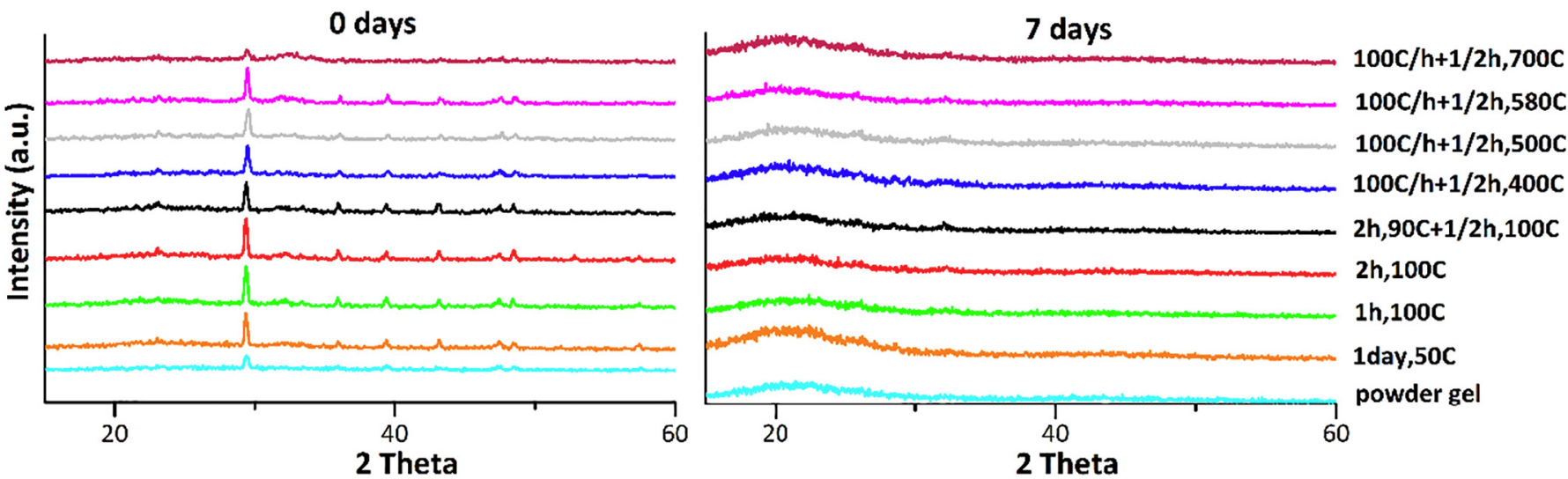

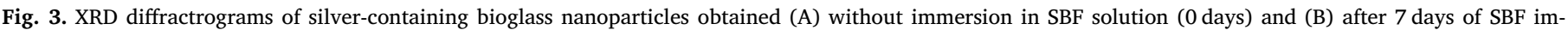
mersion.

the effect of the calcination temperature on their morphologic appearance, comparing the lower with higher temperatures, their resulting morphology was slightly different, but AgBGs calcined with higher temperatures $\left(500^{\circ} \mathrm{C}, 580^{\circ} \mathrm{C}\right.$ and $700{ }^{\circ} \mathrm{C}$ ), appeared to be more aggregated, which could be provided by the fixation of calcium, phosphorus and silver into glassy structure. Comparing this quaternary system $\left[\mathrm{SiO}_{2}-\mathrm{CaO}-\mathrm{P}_{2} \mathrm{O}_{5}-\mathrm{Ag}_{2} \mathrm{O}: 56-30-4-10(\% \mathrm{~mol})\right]$ with the binary [SiO ${ }_{2}-\mathrm{CaO}: 70-30$ (mol\%)] and the ternary $\left[\mathrm{SiO}_{2}-\mathrm{CaO}-\mathrm{P}_{2} \mathrm{O}_{5}: 55-40-5\right.$ (mol\%)] systems developed by Luz and Mano [30], their nanoparticles showed a spherical form with thermal treatments of $700{ }^{\circ} \mathrm{C}$. In the present work, all produced AgBGs did not present this spherical geometry, probably because the silver addition could contribute for a higher agglomeration due to the covalent bonding resulting from later condensations reactions (during the drying step), which could difficult the chemical stabilization of this quaternary bioglass network. However, considering the global SEM results and also the study of Delben et al. [25], which mentioned that AgBGs can stabilize at temperatures around $510^{\circ} \mathrm{C}$, the thermal treatment $100^{\circ} \mathrm{C} / \mathrm{h}+1 / 2 \mathrm{~h}, 580^{\circ} \mathrm{C}$ seems to be more reasonable.

In order to obtain further information about the morphology of distinct nanoparticles produced, S-TEM analysis was also performed and the results obtained were shown in Fig.S1. According to Luz and Mano's findings [35], if there is a strong contrast between the dark edge and the pale center of the particles, the nanoparticles are hollow. If not, they are dense. So, based on the results obtained, all nanoparticles (thermally treated and non-thermally treated) reveals to be dense. Particularly, Fig. S1A evidences that the non-thermally treated AgBGs (powder gel) showed a lower aggregated structure than all calcined powders. In fact, according to the SEM micrographs results (vide Fig. 2), the thermal treatment probably induced the aggregation of these Ag nanoparticles, changing slightly their morphology. Moreover, these S-TEM images showed that all thermally treated Ag powders present a similar aggregated structure, where nanoparticles did not have a spherical form, instead they present a morula-like structure [35]. Indeed, these S-TEM analysis complements the findings obtained from SEM micrographs (Fig. 2), evidencing that AgBGs treated with moderate temperatures $\left(400{ }^{\circ} \mathrm{C}-580^{\circ} \mathrm{C}\right)$ present more uniformity on their diameters. These results are in agreement with Mariappan and Ranza' work [29], which reported that the size of glass nanoparticles slightly increased with calcination temperature, due to their agglomerated structure.

\subsection{In vitro bioactivity tests}

Regarding the composition of bioactive nanoparticles, it has been stated that their silica component has a critical importance in the mineralization of materials [9], as well as phosphorus, which also plays an important role in bioactivity [35]. For these reasons, nanoparticles composed by bioglass as it was developed in this work present an advantage [35], since they have an important capability to replace damaged mineralized tissues like bone.

In order to investigate if the developed AgBGs (with $10 \mathrm{~mol} \% \mathrm{Ag}_{2} \mathrm{O}$ and $4 \mathrm{~mol} \% \mathrm{P}_{2} \mathrm{O}_{5}$ ) have this bioactive character, in vitro bioactivity tests were performed by SBF immersion during 7 days. Fig. 3A and Fig. 3B represents the XRD patterns with and without immersion in SBF after 7 days, respectively. In Fig. 3A, the characteristic peaks of $\mathrm{CaCO}_{3}$ are well evidenced, similarly with Vulpoi et al. findings, the XRD patterns of nanoparticles before SBF immersion showed a broad halo of noncrystalline calcium phosphate matrix, with weak features of an apatitelike phase [38].This appearance is due to the insufficient ammonium hydroxide $\left(\mathrm{NH}_{4} \mathrm{OH}\right)$ added during the nanoparticles synthesis, since it was not sufficient to increase the gelation time in order to prevent the reaction of $\mathrm{Ca}^{2+}$ ions with the oxygen present in the air and consequently, the formation of $\mathrm{CaCO}_{3}$ [39]. Moreover, after SBF immersion (Fig. 3B), the $\mathrm{CaCO}_{3}$ (Rhombohedral, pattern: 00-005-0586) is present in all XRD patterns and it was detected the characteristic peaks of hydroxyapatite- $\left(\mathrm{Ca}_{5}\left(\mathrm{PO}_{4}\right)_{3}(\mathrm{OH})\right.$, Hexagonal, pattern: 01-089-4405) for powders treated with $100{ }^{\circ} \mathrm{C} / \mathrm{h}+580^{\circ} \mathrm{C}, 1 / 2 \mathrm{~h}$, and $100^{\circ} \mathrm{C} /$ $\mathrm{h}+700^{\circ} \mathrm{C}, 1 / 2 \mathrm{~h}$. Some weak peaks of silver carbonate $\left(\mathrm{Ag}_{2} \mathrm{CO}_{3}\right.$, Hexagonal, Pattern:00-031-1237) were only detected for AgBGs powders treated with lower temperatures $\left(50{ }^{\circ} \mathrm{C}, 1\right.$ day; $90^{\circ} \mathrm{C}, 2 \mathrm{~h}+100^{\circ} \mathrm{C}, 1 / 2 \mathrm{~h}$; $100^{\circ} \mathrm{C}, 1 \mathrm{~h} ; 100^{\circ} \mathrm{C}, 2 \mathrm{~h}$ ), which could be related with a quick silver releasing profile for these specific AgBGs powders, caused by an insufficient thermal treatment, which did not provide a chemical stability of quaternary bioglass structure. On the other hand, Fig. 3B illustrates an amorphous halo, where it is possible to detect the presence of hydroxyapatite $\left[\mathrm{Ca}_{5}\left(\mathrm{PO}_{4}\right)_{3}(\mathrm{OH})\right]$ in all samples, corroborating their bioactivity character, crucial for the envisaged applications. Moreover, all AgBGs powders evidenced to be more amorphous than ternary system [30], since the crystallinity of tricalcium phosphate dramatically decreased and this fact is in agreement with Hong and co-workers' findings [40], which evidenced that the crystallinity of $\mathrm{Ca}_{3}\left(\mathrm{PO}_{2}\right)$ increases with phosphate content.

The capability of these nanoparticles to induce hydroxyapatite formation upon immersion in SBF was further investigated by SEM-EDS analysis-Fig.4A-I. Comparing the EDS analysis before and after SBF immersion, unsurprisingly, it can be seen that there was a generally decrease of $\mathrm{Si}$ and an increase of $\mathrm{Ca}$ and $\mathrm{P}$ weight percentages, as it was reported in similar works $[30,40]$. On the other hand, EDS data reveal that increasing the calcination temperature $\left(>400^{\circ} \mathrm{C}\right)$ favors a slower release of silver through the ionic exchange between AgBGs and the SBF solution, since for heat-treatments above $400{ }^{\circ} \mathrm{C}$, silver content was not detected. In fact, this slower silver ion releasing profile was already mentioned by others authors [12,19,31], and it could be useful for a 


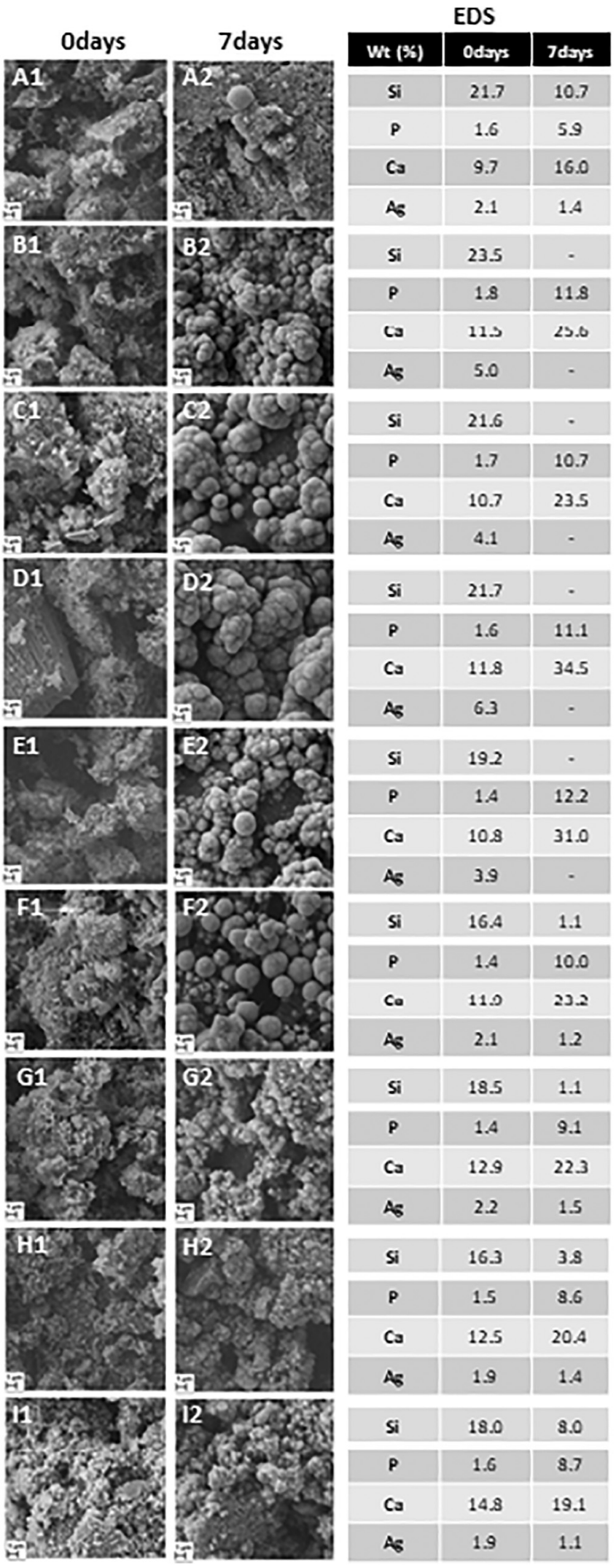

Fig. 4. In vitro bioactivity studies. Representative SEM images and respective quantitative EDS analysis of AgBGs (A-I) before and after SBF immersion for 7 days. Scale bar represents $1 \mu \mathrm{m}$. controllable antibacterial effect. Nevertheless, El Kady et al. [12] mentioned that replacing calcium with silver in the bioactive glass matrix reduced the number of non-bridging oxygen groups available for the dissolution of silica, and consequently, it tends to reduce the bioglass dissolution. Furthermore, the corresponding SEM micrographs revealed the presence of hydroxyapatite with its typical cauliflower morphology. In fact, an ion exchange occurs when bioglass nanoparticles are soaked in SBF. The presence of $\mathrm{H}_{3} \mathrm{O}^{+}$in solution with $\mathrm{Ca}^{2+}$ and $\mathrm{Na}^{+}$ions implies a pH increase of the solution and the formation of hydrated titania or silica $[39,41]$. The formation of a crystalline calcium phosphate $(\mathrm{Ca}-\mathrm{P})$ layer has place after this hydrated titanium or silica ( $\mathrm{Si}-\mathrm{OH}$ or $\mathrm{Ti}-\mathrm{OH}$ ) formation [39], because it serves as nucleation sites [41]. Summarizing, SEM-EDS results are in agreement with XRD data, confirming that both non-treated and thermally treated nanoparticles have bioactive properties.

\subsection{Antibacterial tests}

In the present work, the antibacterial properties of the quaternary bioactive system developed were tested with six AgBGs powders $\left(90^{\circ} \mathrm{C}, 2 \mathrm{~h}+100^{\circ} \mathrm{C}, \frac{1 / 2}{\mathrm{~h}} ; 100^{\circ} \mathrm{C} / \mathrm{h}+400^{\circ} \mathrm{C}, \frac{1}{2} \mathrm{~h} ; 100^{\circ} \mathrm{C} / \mathrm{h}+500{ }^{\circ} \mathrm{C}, \frac{1}{2} \mathrm{~h}\right.$; $\left.100^{\circ} \mathrm{C} / \mathrm{h}+580^{\circ} \mathrm{C}, 1 / 2 \mathrm{~h} ; 130^{\circ} \mathrm{C}, 24 \mathrm{~h}+600^{\circ} \mathrm{C}, 4 \mathrm{~h} ; 100^{\circ} \mathrm{C} / \mathrm{h}+700^{\circ} \mathrm{C}, 1 / 2 \mathrm{~h}\right)$, in comparison with $\mathrm{BGs}$ and also silver nitrate. It was included an AgBG condition previously synthesized by our group, AgBGs-

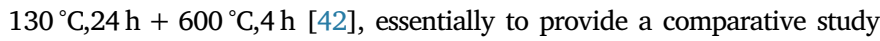
about their antibacterial properties. Fig. 5 shows representative images of $E$. coli and $S$. aureus cultures that were grown for $16 \mathrm{~h}$ in direct contact with AgBGs and BGs powders. In addition, Fig. S2 shows representative images from bacterial cultures that grow with silver nitrate. As data show, it is clear that only plates with BGs did not present any inhibitory zone around powders, consistently with previous studies conducted with silver nanoparticles [7,19,26,29,42-44], where it was confirmed that bioactive glasses do not present antibacterial properties.

The antibacterial properties of silver ions has been described through distinct mechanisms. It is believed that silver ions can interact with disulfide (S-S) and sulfhydryl $(-\mathrm{SH})$ groups of the surface proteins of microbial cell walls, which stops respiration and electron transfer, leading to bacterial cell death [24]. Another proposed mechanism is related to the leakage of the $\mathrm{Ag}^{+}$through the bacteria cell membrane, which results in the disruption of the bacterial membrane, followed by the entrance of $\mathrm{Ag}^{+}$into the cytoplasm, which can induce further damages, such as interfering with DNA replication. [45] Additionally, $\mathrm{Ag}^{+}$ions can stimulate the production of reactive oxygen species (ROS), which results in augmented damages to proteins, DNA, RNA and lipids, and eventually causing bacteria cell death [46]. As Bellantone et al. [19] already described, besides BGs induce similar changes in $\mathrm{pH}$ and ionic content to those provoked by AgBGs, BGs without silver ions did not exhibit antibacterial action. In fact, bacterial cultures incubated with AgBGs powders and their precursor of silver $\left(\mathrm{AgNO}_{3}\right)$ demonstrated a bright inhibitory zone formed around powders, meaning that the quaternary bioglass system $\left[\mathrm{SiO}_{2}-\mathrm{CaO}-\mathrm{P}_{2} \mathrm{O}_{5}-\right.$ $\mathrm{Ag}_{2} \mathrm{O}$ (mol\%):56-30-4-10] exhibited antibacterial properties exclusively due to the leaching of ionic silver from the glass matrix (Fig. S2). It should be mentioned that the oxidation states of silver (silver ion/silver metal) in the silicate glass matrix is crucial, being reported that Ag-BGs containing $\mathrm{Ag}^{+}$exhibited higher bactericidal effect than those containing silver with higher oxidation states [20,29]. Since XRD patterns did not reveal silver-related crystalline phase (metallic silver nanocrystals), silica ions did not get released easily from the powders. As a result, silver ions could only be released from the powders via ion exchange between $\mathrm{Ag}^{+}$ion and hydronium $\left(\mathrm{H}_{3} \mathrm{O}^{+}\right)$ion from surrounding water. The release of $\mathrm{Ag}^{+}$ion is controlled by the rate of interdiffusion of these ions within the AgBG powders. [47] 


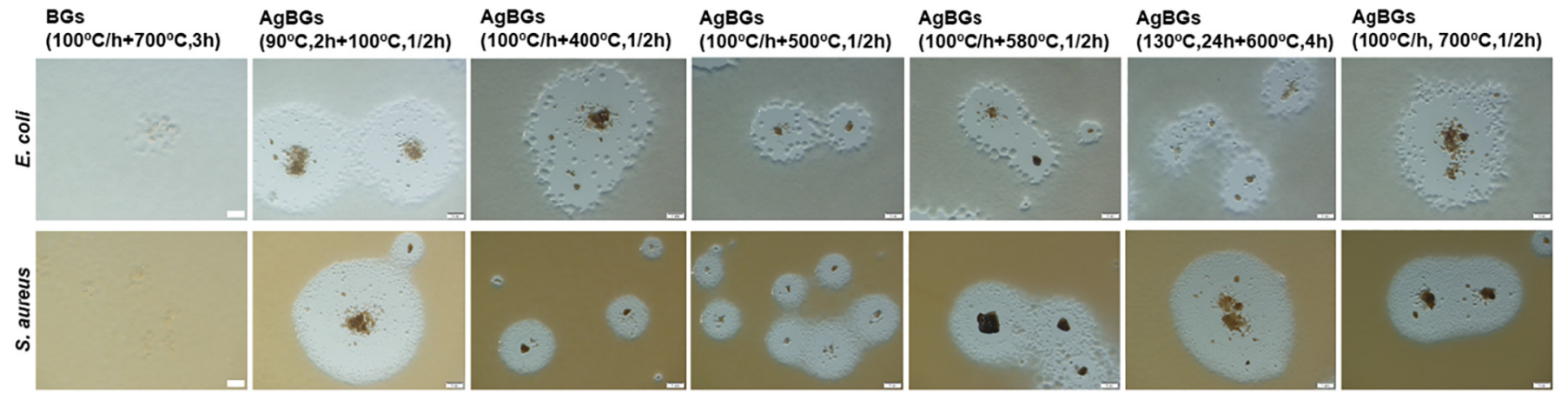

Fig. 5. Images of Mueller-Hinton agar plates $16 \mathrm{~h}$ after being inoculated at $37^{\circ} \mathrm{C}$ with a culture of $S$. aureus( + ) or E. coli( -$)$ in direct contact with BGs and AgBGs $\left(90{ }^{\circ} \mathrm{C}, 2 \mathrm{~h}+100^{\circ} \mathrm{C}, 1 / 2 \mathrm{~h} ; 100^{\circ} \mathrm{C} / \mathrm{h}+400{ }^{\circ} \mathrm{C}, 1 / 2 \mathrm{~h} ; 100^{\circ} \mathrm{C} / \mathrm{h}+500^{\circ} \mathrm{C}, 1 / 2 \mathrm{~h} ; 100^{\circ} \mathrm{C} / \mathrm{h}+580^{\circ} \mathrm{C}, 1 / 2 \mathrm{~h} ; 130{ }^{\circ} \mathrm{C}, 24 \mathrm{~h}+600^{\circ} \mathrm{C}, 4 \mathrm{~h} ; 100^{\circ} \mathrm{C} / \mathrm{h}+700^{\circ} \mathrm{C}, 1 / 2 \mathrm{~h}\right) . \quad$ Scale bar represents $1 \mathrm{~mm}$.

This inhibitory zone formed around AgBGs powders was relatively small but it was quite similar with results obtained in previous works $[7,8,19,26,42,43,47,48]$, and this fact is related with the diffusion-

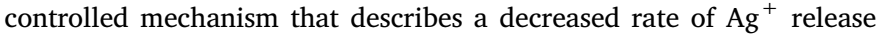
from the bioglass matrix, due to the higher electronegativity of silver ion and, consequently, the strong covalent $\mathrm{Ag}-\mathrm{O}$ bond in the glass structure $[12,17]$.

Moreover, it was also found that the studied thermal treatments did not affect the antibacterial properties of AgBGs, since the size of inhibitory zone did not change for distinct AgBGs powders. Nevertheless, that particular releasing profile of silver from AgBGs could be further investigated and improved, in order to develop AgBGs with a tunable $\mathrm{Ag}^{+}$release, promoting their long-term antibacterial effects.

\section{Conclusions}

Silver-containing bioglass nanoparticles $\left[\mathrm{SiO}_{2}-\mathrm{CaO}-\mathrm{P}_{2} \mathrm{O}_{5}-\mathrm{Ag}_{2} \mathrm{O}\right.$ (mol\%):56-30-4-10] were successfully produced through a modified sol-gel methodology. SEM and EDS data showed the production of nano-sized particles with diameter between 50 and $200 \mathrm{~nm}$, as well as the silver incorporation into the bioglass matrix. Moreover, S-TEM results revealed that these quaternary glass nanoparticles are dense, evidencing an aggregated structure, called the morula-like structure, in contrast with the spherical morphology reported for the ternary system. Regarding the effect of thermal treatments on the morphological properties of these Ag nanoparticles, SEM-EDS and S-TEM results indicated that the higher temperatures tend to slightly increase the AgBGs aggregation. However, considering that the stabilization temperature of the AgBGs is around $510^{\circ} \mathrm{C}, 100^{\circ} \mathrm{C} / \mathrm{h}+580^{\circ} \mathrm{C}, 1 / 2 \mathrm{~h}$ revealed to be the thermal treatment more suitable for these $\mathrm{Ag}$ nanoparticles. From the in vitro bioactivity studies, SEM-EDS and XRD results clearly evidenced the presence of hydroxyapatite onto the surface of all AgBGs nanoparticles, confirming their bioactive behavior. In addition, from the antibacterial tests, even when distinct thermal treatments were applied, there was an indication that the quaternary bioactive formulation developed in this work have promising antibacterial properties against $S$. aureus and E. coli bacteria. Summarizing, these silver-containing bioglass nanoparticles have interesting properties that could be improved and further used in the biomedical field, for instance, for production of composite films and hydrogels for orthopedic or dental applications.

Supplementary data to this article can be found online at https:// doi.org/10.1016/j.msec.2018.09.027.

\section{Declaration of interest}

The authors declare no conflict of interest.

\section{Acknowledgements}

The authors acknowledge the Portuguese Foundation for Science and Technology (FCT) and the European program FEDER/COMPETE for the financial support through projects PTDC/BTM-MAT/28123/ 2017 and PTDC/NAN-MAT/31036/2017. ACV thanks Dr. Edith Ariza Avila and Mara Teixeira (SEMAT/UM) for their valuable contribution in SEM and XRD analysis, respectively.

\section{References}

[1] T. Ienaga, S. Okada, Y. Nakahara, M. Watanabe, T. Tamai, S. Yajima, K. Kimura, Comparison of physical adsorption strength of protective agents via ligand exchange of silver nanoparticles prepared by vacuum evaporation on running oil substrate, Bull. Chem. Soc. Jpn. 90 (2017) 1251-1258.

[2] M. Lykaki, E. Pachatouridou, E. Iliopoulou, S.A.C. Carabineiro, M. Konsolakis, Impact of the synthesis parameters on the solid state properties and the $\mathrm{CO}$ oxidation performance of ceria nanoparticles, RSC Adv. 7 (2017) 6160-6169.

[3] S. Ghasemi, S. Karim, Mizoroki-heck cross-coupling reaction of Haloarenes mediated by a well-controlled modified polyacrylamide brush grafted silica/Pd nanoparticle system, Bull. Chem. Soc. Jpn. 90 (2017) 485-490.

[4] Q. Yang, Q. Xu, H.-L. Jiang, Metal-organic frameworks meet metal nanoparticles: synergistic effect for enhanced catalysis, Chem. Soc. Rev. 46 (2017) 4774-4808.

[5] A.R. Boccaccini, M. Erol, W.J. Stark, D. Mohn, Z. Hong, J.F. Mano, Polymer/ bioactive glass nanocomposites for biomedical applications: a review, Compos. Sci. Technol. 70 (2010) 1764-1776.

[6] M.A. Shenashen, S.A. El-Safty, E.A. Elshehy, Synthesis, morphological control, and properties of silver nanoparticles in potential applications, Part. Part. Syst. Charact. 31 (2014) 293-316.

[7] Y.-F. Goh, A.Z. Alshemary, M. Akram, M.R. Abdul Kadir, R. Hussain, Bioactive glass: an in-vitro comparative study of doping with nanoscale copper and silver particles, Int. J. Appl. Glas. Sci. 5 (2014) 255-266.

[8] F.E. Ciraldo, L. Liverani, L. Gritsch, W.H. Goldmann, A.R. Boccaccini, Synthesis and characterization of silver-doped mesoporous bioactive glass and its applications in conjunction with electrospinning, Dent. Mater. 11 (2018) 692.

[9] Z. Hong, G.M. Luz, P.J. Hampel, M. Jin, A. Liu, X. Chen, J.F. Mano, Mono-dispersed bioactive glass nanospheres: preparation and effects on biomechanics of mammalian cells, J. Biomed. Mater. Res. A 95A (2010) 747-754.

[10] J.R. Jones, Reprint of: review of bioactive glass: from Hench to hybrids, Acta Biomater. 23 (Suppl) (2015) S53-S82.

[11] K. Zheng, A.R. Boccaccini, Sol-gel processing of bioactive glass nanoparticles: a review, Adv. Colloid Interf. Sci. 249 (2017) 363-373.

[12] A.M. El-Kady, A.F. Ali, R.A. Rizk, M.M. Ahmed, Synthesis, characterization and microbiological response of silver doped bioactive glass nanoparticles, Ceram. Int 38 (2012) 177-188.

[13] R. Payami, M. Ghorbanpour, A. Parchehbaf Jadid, Antibacterial silver-doped bioactive silica gel production using molten salt method, J Nanostructure Chem. 6 (2016) 215.

[14] S. Lin, C. Ionescu, K.J. Pike, M.E. Smith, J.R. Jones, Nanostructure evolution and calcium distribution in sol-gel derived bioactive glass, J. Mater. Chem. 19 (2009) 1276-1282.

[15] C. Vichery, J.-M. Nedelec, Bioactive glass nanoparticles: from synthesis to materials design for biomedical applications, Dent. Mater. 9 (2016) 288.

[16] D. Kozon, K. Zheng, E. Boccardi, Y. Liu, L. Liverani, A. Boccaccini, Synthesis of monodispersed Ag-doped bioactive glass nanoparticles via surface modification, Dent. Mater. 9 (4) (2016) 225.

[17] Q.L. Feng, J. Wu, G.Q. Chen, F.Z. Cui, T.N. Kim, J.O. Kim, A mechanistic study of the antibacterial effect of silver ions on Escherichia coli and Staphylococcus aureus, J. Biomed. Mater. Res. A 52 (2000) 662-668.

[18] M.C. Bellantone, J. N, L.L. Hench, A novel sol-gel derived bioactive glass featuring 
antibacterial properties, Key Eng. Mater. 192-195 (2001) 597-600.

[19] M. Bellantone, H.D. Williams, L.L. Hench, Broad-spectrum bactericidal activity of Ag(2)O-doped bioactive glass, Antimicrob. Agents Chemoter. 46 (2002) 1940-1945.

[20] S.P. Valappil, J.C. Knowles, M. Wilson, Effect of silver-doped phosphate-based glasses on bacterial biofilm growth, Appl. Environ. Microbiol. 74 (2008) $5228-5230$

[21] K. Zheng, X. Dai, M. Lu, N. Hüser, N. Taccardi, A.R. Boccaccini, Synthesis of coppercontaining bioactive glass nanoparticles using a modified Stöber method for biomedical applications, Colloids Surf. B Interfaces 150 (2017) 159-167.

[22] A. Simchi, E. Tamjid, F. Pishbin, A.R. Boccaccini, Recent progress in inorganic and composite coatings with bactericidal capability for orthopaedic applications, Nanomed. Nanotechnol. 7 (2011) 22-39.

[23] J.J. Blaker, S.N. Nazhat, A.R. Boccaccini, Development and characterisation of silver-doped bioactive glass-coated sutures for tissue engineering and wound healing applications, Biomaterials 25 (2004) 1319-1329.

[24] K. Mijnendonckx, N. Leys, J. Mahillon, S. Silver, R. Van Houdt, Antimicrobial silver: uses, toxicity and potential for resistance, Biometals 26 (2013) 609-621.

[25] J.R.J. Delben, O.M. Pimentel, M.B. Coelho, P.D. Candelorio, L.N. Furini, F. Alencar Dos Santos, F.S. de Vicente, A.A.S.T. Delben, Synthesis and thermal properties of nanoparticles of bioactive glasses containing silver, J. Therm. Anal. Calorim. 97 (2009) 433.

[26] M. Bellantone, N.J. Coleman, L.L. Hench, Bacteriostatic action of a novel fourcomponent bioactive glass, J. Biomed. Mater. Res. 51 (2000) 484-490.

[27] M. Catauro, M.G. Raucci, F. de Gaetano, A. Marotta, Antibacterial and bioactive silver-containing $\mathrm{Na}_{2} \mathrm{O} \cdot \mathrm{CaO} \cdot 2 \mathrm{SiO}_{2}$ glass prepared by sol-gel method, J. Mater. Sci. Mater. Med. 15 (2004) 831-837.

[28] E. Vernè, S.D. Nunzio, M. Bosetti, P. Appendino, C. Vitale Brovarone, G. Maina, M. Cannas, Surface characterization of silver-doped bioactive glass, Biomaterials 26 (2005) 5111-5119.

[29] C.R. Mariappan, N. Ranga, Influence of silver on the structure, dielectric and antibacterial effect of silver doped bioglass-ceramic nanoparticles, Ceram. Int. 43 (2017) 2196-2201.

[30] G.M. Luz, J.F. Mano, Preparation and characterization of bioactive glass nanoparticles prepared by sol-gel for biomedical applications, Nanotechnology 22 (2011) 494014.

[31] A. Vulpoi, C. Gruian, E. Vanea, L. Baia, S. Simon, H.J. Steinhoff, G. Göller, V. Simon, Bioactivity and protein attachment onto bioactive glasses containing silver nanoparticles, J. Biomed. Mater. Res. A 100A (2012) 1179-1186.

[32] A. Oyane, H.-M. Kim, T. Furuya, T. Kokubo, T. Miyazaki, T. Nakamura, Preparation and assessment of revised simulated body fluids, J. Biomed. Mater. Res. A 65A (2003) 188-195.
[33] A. Oyane, K. Onuma, A. Ito, H.-M. Kim, T. Kokubo, T. Nakamura, Formation and growth of clusters in conventional and new kinds of simulated body fluids, J. Biomed. Mater. Res. A 64A (2003) 339-348.

[34] J. Ma, C.Z. Chen, D.G. Wang, X.G. Meng, J.Z. Shi, In vitro degradability and bioactivity of mesoporous $\mathrm{CaO}-\mathrm{MgO}-\mathrm{P}_{2} \mathrm{O}_{5}-\mathrm{SiO}_{2}$ glasses synthesized by sol-gel method, J Solgel Sci. Technol. 54 (2010) 69-76.

[35] G.M. Luz, J.F. Mano, Nanoengineering of bioactive glasses: hollow and dense nanospheres, J. Nanopart. Res. 15 (2013) 1457.

[36] H.H. Lu, S.R. Pollack, P. Ducheyne, Temporal zeta potential variations of 45S5 bioactive glass immersed in an electrolyte solution, J. Biomed. Mater. Res. 51 (2000) 80-87.

[37] M. Tirrell, E. Kokkoli, M. Biesalski, The role of surface science in bioengineered materials, Surf. Sci. 500 (2002) 61-83.

[38] A. Vulpoi, L. Baia, S. Simon, V. Simon, Silver effect on the structure of $\mathrm{SiO}_{2}-\mathrm{CaO}-$ $\mathrm{P}_{2} \mathrm{O}_{5}$ ternary system, Mater. Sci. Eng. C 32 (2012) 178-183.

[39] H.M. Kim, Ceramic bioactivity and related biomimetic strategy, Curr. Opin. Solid State Mater. Sci. 7 (2003) 289-299.

[40] Z. Hong, R.L. Reis, J.F. Mano, Preparation and in vitro characterization of novel bioactive glass ceramic nanoparticles, J. Biomed. Mater. Res. A 88 (2009) 304-313.

[41] N.M. Alves, I.B. Leonor, H.S. Azevedo, R.L. Reis, J.F. Mano, Designing biomaterials based on biomineralization of bone, J. Mater. Chem. 20 (2010) 2911-2921.

[42] A.C. Vale, A.L. Carvalho, A.M. Barbosa, E. Torrado, J.F. Mano, N.M. Alves, Novel antibacterial and bioactive silicate glass nanoparticles for biomedical applications, Adv. Eng. Mater. 20 (2018) 1700855.

[43] C.S. Ciobanu, S.L. Iconaru, P. Le Coustumer, L.V. Constantin, D. Predoi, Antibacterial activity of silver-doped hydroxyapatite nanoparticles against grampositive and gram-negative bacteria, Nanoscale Res. Lett. 7 (1) (2012) 324.

[44] H. Palza, B. Escobar, J. Bejarano, D. Bravo, M. Diaz-Dosque, J. Perez, Designing antimicrobial bioactive glass materials with embedded metal ions synthesized by the sol-gel method, Mater. Sci. Eng. C 33 (2013) 3795-3801.

[45] S. Eckhardt, P.S. Brunetto, J. Gagnon, M. Priebe, B. Giese, K.M. Fromm, Nanobio silver: its interactions with peptides and bacteria, and its uses in medicine, Chem. Rev. 113 (2013) 4708-4754.

[46] Z.M. Xiu, J. Ma, P.J. Alvarez, Differential effect of common ligands and molecular oxygen on antimicrobial activity of silver nanoparticles versus silver ions, Environ. Sci. Technol. 45 (2011) 9003-9008.

[47] M. Kawashita, S. Tsuneyama, F. Miyaji, T. Kokubo, H. Kozuka, K. Yamamoto, Antibacterial silver-containing silica glass prepared by sol-gel method, Biomaterials 21 (2000) 393-398.

[48] A. Hilonga, J.-K. Kim, P.B. Sarawade, D.V. Quang, G. Shao, G. Elineema, H.T. Kim, Silver-doped silica powder with antibacterial properties, Powder Technol. 215-216 (2012) 219-222. 